\title{
SARS-CoV-2 (COVID-19): What do we know about children? A systematic review
}

Nisha S. Mehta MA (Oxon), MBBS, MRCPsych, MRCGP

Clinical Advisor to the Chief Medical Officer (England), Department of Health and Social Care

(England), London, UK

Oliver T. Mytton BM, BCh, MA, MRCP, MPH, MFPH, PhD

NIHR Academic Clinical Lecturer, University of Cambridge, Cambridge, UK

Edward W. S. Mullins PhD, MRCOG

Clinical Advisor to the Chief Medical Officer (England)

NIHR Academic Clinical Lecturer, Imperial College London, London, UK

Post-CCT, Obstetrics and Gynaecology, Queen Charlotte's and Chelsea Hospital, London, UK

Tom A. Fowler FFPH, PhD, MPH

Deputy Chief Scientist, Genomics England, London, UK

Catherine L. Falconer MSc, MPH, PhD, MFPH

Acting Consultant in Public Health, Somerset County Council, Taunton, UK

Orla B. Murphy

Chief Medical Officer's Independent Annual Reports Manager (England), Department of Health and Social Care (England), London, UK

Claudia Langenberg, Dr med, MSc, PhD, FFPH

Programme Lead, MRC Epidemiology Unit, University of Cambridge, Cambridge UK

Hon Consultant Physician, Public Health England, London, UK

Clinician in Residence, The Francis Crick Institute, London, UK

Wikum J. P. Jayatunga MBBS, BSc, MSc, MFPH

Public Health Registrar to the Chief Medical Officer (England), Department of Health and Social Care (England), London, UK

Danielle H. Eddy MRCPCH, MBBCh, BSc, PGCert

National Clinical Director's Fellow, Public Health England, London, UK

Jonathan S. Nguyen-Van-Tam MBE, BMedSci, BMBS, DM, FFPH, FRCPath, FRSB, FRSPH, Hon FFPM Deputy Chief Medical Officer, Department of Health and Social Care (England), London, UK Professor of Health Protection, University of Nottingham School of Medicine, Nottingham UK

(C) The Author(s) 2020. Published by Oxford University Press for the Infectious Diseases Society of America.

This is an Open Access article distributed under the terms of the Creative Commons AttributionNonCommercial-NoDerivs licence (http://creativecommons.org/licenses/by-nc-nd/4.0/), which permits non-commercial reproduction and distribution of the work, in any medium, provided the original work is not altered or transformed in any way, and that the work is properly cited. For commercial re-use, please contact journals.permissions@oup.com 
Corresponding author: Nisha Mehta, Department of Health and Social Care, 39 Victoria Street, London, SW1H 0EU, UK Email: nisha.mehta@dhsc.gov.uk

Summary: Initial reports from China observed low rates of COVID-19 in children compared to adults. Emerging evidence suggests that children may be infected the same rate as adults but are more likely to experience asymptomatic or mild disease. 


\section{Abstract}

\section{BACKGROUND}

Few paediatric cases of COVID-19 have been reported and we know little about the epidemiology in children, though more is known about other coronaviruses. We aimed to understand the infection rate, clinical presentation, clinical outcomes and transmission dynamics for SARS-CoV-2, in order to inform clinical and public health measures.

\section{METHODS}

We undertook a rapid systematic review and narrative synthesis of all literature relating to SARSCoV-2 in paediatric populations. The search terms also included SARS-CoV and MERS-CoV. We searched three databases and the COVID-19 resource centres of eleven major journals and publishers. English abstracts of Chinese language papers were included. Data were extracted and narrative syntheses conducted.

\section{RESULTS}

24 studies relating to COVID-19 were included in the review. Children appear to be less affected by COVID-19 than adults by observed rate of cases in large epidemiological studies. Limited data on attack rate indicate that children are just as susceptible to infection. Data on clinical outcomes are scarce but include several reports of asymptomatic infection and a milder course of disease in young children, though radiological abnormalities are noted. Severe cases are not reported in detail and there are little data relating to transmission. 


\section{CONCLUSIONS}

Children appear to have a low observed case rate of COVID-19 but may have similar rates to adults of infection with SARS-CoV-2. This discrepancy may be because children are asymptomatic or too mildly infected to draw medical attention, be tested and counted in observed cases of COVID-19.

Keywords: coronavirus, SARS-CoV-2, COVID-19, children, infection, transmission 


\section{Introduction}

In December 2019 reports emerged of a cluster of cases of pneumonia of unknown cause in Wuhan City, China, culminating in the identification of a novel coronavirus on $12^{\text {th }}$ January 2020 , denoted as SARS-CoV-2, and the associated disease as COVID-19.[1] The virus spread rapidly around the world and was declared a pandemic by World Health Organization (WHO) on $11^{\text {th }}$ March 2020,[2] with many countries adopting unprecedented public health measures to curb its spread.

Coronaviruses are large, lipid-enveloped, single-stranded RNA viruses found in avian and mammalian species. Human coronaviruses commonly cause mild upper respiratory tract infections, accounting for about $30 \%$ of common colds, although instances of severe disease are described in the elderly, children and immunocompromised hosts.[3] Besides SARS-CoV-2, there are two other notable exceptions: Severe Acute Respiratory Syndrome coronavirus (SARS-CoV) and Middle East Respiratory Syndrome coronavirus (MERS-CoV). An epidemic of SARS-CoV in 2003 affected 26 countries and resulted in more than 8000 cases and 774 deaths. [4] MERS-CoV was first reported in 2012, and is now endemic at low levels in the Persian Gulf region, with notable nosocomial outbreaks but otherwise limited human-human transmission.[5] As of $19^{\text {th }}$ November 2019, WHO has reported 2494 cases and 858 deaths. [5] The respective Ro values for SARS-CoV, MERS-CoV and SARS-CoV-2 (outside nosocomial outbreaks) are 3,[4] $<1,[6]$ and 2-3.[7]

Social distancing policies have been widely adopted in many countries to limit spread of SARS-CoV-2, at great economic and social cost. Social-distancing policies that apply to children, such as school closures, may have an important role in mitigating the spread of pandemics; for many infectious diseases, such as influenza, children are known to drive transmission in households and communities. However, early reports of SARS-CoV-2,[1] as well as MERS-CoV and SARS-CoV, suggest that children are less likely to be infected and to develop serious disease compared to adults. 
We undertook a narrative review of the emerging literature on SARS-CoV-2 to summarise current understanding of the epidemiology and transmission dynamics of this coronavirus in children, in order to inform decisions regarding clinical and public health measures for children in the UK.

\section{Methods}

We searched MEDLINE, MedRxiv and the COVID-19 literature resources of WHO and major journals, for all English-language papers concerning SARS-CoV, SARS-CoV-2 or MERS-CoV, in children, up to $9^{\text {th }}$ March 2020.

The MEDLINE search used the following search terms: 'coronavirus OR Severe acute respiratory syndrome OR covid-19 OR nCOV OR COVID OR SARS OR MERS OR middle east respiratory syndrome) AND (Child OR Children OR childhood OR preschool OR infant OR babies OR baby OR neonates OR paediatrics OR paediatric OR pediatrics OR pediatric.' The MedRxiv search used the term 'coronavirus'. We searched the WHO COVID-19 literature database using the terms: 'child, children, childhood, infant, baby, babies, pediatric, paediatric'. To account for papers not yet indexed in databases, we also hand searched COVID-19 resource centres from the following journals and publishers, by manually trawling the collections for relevant titles: BMJ; Cambridge University Press; Elsevier; JAMA Network; The Lancet; New England Journal of Medicine; Oxford University Press; PLOS; Springer Nature; SSRN (reprints); Wiley.

Inclusion criteria were any study or article that included information about infection risk, transmission or severity in children (aged under 18 years) for SARS-CoV-2. All types of study and countries of origin were eligible for inclusion. Our broader search also identified papers relating to SARS-COV and MERS-CoV, to allow for informative comparison, though this was not the focus of the 
review. We excluded articles that exclusively reported data on adults or other respiratory viruses, that did not relate to the clinical or epidemiological aspects of interest, and that were not written in the English language. Eight reviewers extracted data on infection risk, transmission, and clinical presentation and outcomes, into a cloud-based spreadsheet (Google Sheets). We also recorded the case definition, the type of study or report and important limitations, though quality was not formally assessed, and findings were synthesised narratively. As this was a rapid review, each paper was reviewed by one reviewer.

\section{Results}

Our search retrieved 1657 records, of which 1552 were excluded via title and abstract screen. 105 full articles were assessed for eligibility and 77 were identified relating to SARS-CoV, MERS-CoV and SARS-CoV-2. Of these, 24 papers relating to SARS-CoV-2 were identified, from which data were extracted and synthesised (see Figure 1). 16 of the included papers were pre-prints or reports not certain to have been subjected to peer review. All COVID-19 papers drew heavily or exclusively on data and experience from China. A summary of the included papers is provided in Table 1. 


\section{Likelihood of infection}

Children are affected by COVID-19, but extant data (largely case series from China) suggests they are less likely to be affected than adults. A national analysis of the first 72,314 cases in China was reported up to $11^{\text {th }}$ February 2020. Cases included $61.8 \%$ laboratory confirmed, $22.4 \%$ suspected, $14.6 \%$ clinically diagnosed and $1.2 \%$ asymptomatic. They reported 419 cases ( $0.9 \%$ of all cases) in children 0-9 years old, and 549 (1.2\%) in children aged 10-19 years old. A case series of all 1212 confirmed cases in Henan province, China, from $24^{\text {th }}$ January 2020 to $14^{\text {th }}$ February 2020, reported a similarly low proportion of affected children.[8] Amongst cases with data on age ( $n=1156), 24$ (2.1\%) cases were in children aged in 0-10 years old, and 31 cases (2.7\%) in children aged 11-20 years old. The youngest patient identified was 28 days old, with several cases reported in neonates.[9] 'Report of the WHO-China Joint Mission on COVID-19' [7] concludes that 'we cannot determine the extent of infection among children, what role children play in transmission, whether children are less susceptible or whether they simply present differently'.

In an early epidemiological analysis of 507 COVID-19 cases, mainly from China, 13 (2.6\%) were younger than 15 years, and the relative risk of COVID-19 in children was less than 0.5 compared to the population average.[10] In contrast, a follow-up study of 1286 close contacts of 391 confirmed cases reported in Shenzhen province, China, reported a similar infection rate (7.4\%) in children under 10 years of age $(n=148)$ and aged $11-19$ years $(7.1 \%)(n=84)$ to the population average $(7.9 \%)$. The close contact cases amongst children were less likely to be severe and less likely to present with fever compared to adults, demonstrating how milder clinical presentation may lead to undercounting of cases. [11] 


\section{Clinical Presentation}

Symptoms of COVID-19 are nonspecific and disease presentation ranges from asymptomatic to severe pneumonia and death.[7] Evidence so far suggests a milder course of disease in children, and some asymptomatic cases, but with evidence of radiological lung changes in both categories. Cai et al[12] reported a case series of 10 paediatric patients (aged 3 months-10 years) with confirmed SARS-CoV-2 infection from four cities in China in February 2020. The symptoms reported were fever (8 patients), cough (6), sore throat (4), nasal congestion (3) and sneezing and rhinorrhoea (2). None of the patients had dyspnoea or diarrhoea during the illness, and fever resolved after 24 hours. Chest X-Ray revealed unilateral patchy infiltrate in four of ten patients. Wei et al[9] identified all hospitalised infants in China diagnosed with COVID-19 infection between $8^{\text {th }}$ December 2019 and $6^{\text {th }}$ February 2020. Nine infected infants were identified (age range 1-11 months) with symptoms reported as fever (4 infants), mild upper respiratory tract symptoms (2), no symptoms (1) and two with no information on symptoms available. None required intensive care or mechanical ventilation.

Asymptomatic infection in children is reported in 14 individual cases, reported in five separate papers. [9,13-16] Notably, in an early report[13] of a familial cluster in China, an asymptomatic 10year-old boy was screened as part of the family cluster and CT chest revealed radiological ground glass lung opacities. In Singapore, a well six-month-old infant with COVID-19 and high viral load was detected as part of a cluster and was also asymptomatic throughout admission.[15] Asymptomatic cases are also reported in the English abstract of a Chinese paper which reports clinical data and CT chest images of 15 children (aged 4-14 years old) diagnosed with COVID-19 in Shenzhen. Five children were febrile and 10 asymptomatic on first visit. The abstract reports radiological changes which are difficult to interpret: 'For their first chest CT images, six patients had no lesions, while nine 
patients had pulmonary inflammation lesions. Seven cases of small nodular ground glass opacities and two cases of speckled ground glass opacities were found.'[16]

\section{Clinical Outcomes}

Whilst most symptomatic cases in children are described as mild, severe cases of the disease have been reported. 'Report of the WHO-China Joint Mission on COVID-19' stated that $2.5 \%$ of the cases amongst those under 19 years old were severe, and 0.2\% were critical.[7] Amongst the 105 children admitted to Wuhan's Children's Hospital, the sole hospital for treating COVID-19 in children in Wuhan, eight (7.6\%) were reported to have severe disease.[17] Amongst the large analysis of 72,314 cases from China, there were no deaths reported amongst the 416 reported cases in children aged 1-9 years, and a single death amongst the 549 cases in children aged $10-19$ years. This equates to a case fatality rate of $0.2 \%$ in those aged $10-19$ years. [18]

\section{Co-morbidities}

There is a suggestion that children with underlying conditions are at greater risk of infection or more severe disease, although the evidence is limited and mixed. Among 31 paediatric cases of SARS-CoV2 (12 asymptomatic and 19 described as mild) outside Wuhan, only two were reported to have underlying conditions (one had asthma, one had a duplicate kidney).[19] Among a series of 20 paediatric patients treated at Wuhan Children's Hospital, seven were reported as having underlying conditions, though these were not specified.[20]

There were no data on underlying conditions from the larger cases series of children from Wuhan Children's Hospital ( $n=105)$. [17] While underlying conditions were noted to be an important risk 
factor in the overall population (particularly respiratory and cardiovascular disease), no paediatric specific data on underlying conditions were presented in the major analyses of Chinese data. $[7,18]$

\section{$\underline{\text { Transmission }}$}

There is limited evidence relating to transmission of SARS-CoV-2 by children. Many of the childhood cases are from familial clusters, with the children tending to be identified through contact tracing of adult cases. $[6,9,20,21]$ Whilst people interviewed by the WHO-China Joint Mission could not recall episodes of a child infecting an adult (or another child),[7] there has subsequently been one clinical report of probable transmission from a 3-month-old infant to her parents. Both parents developed symptomatic COVID-19 days after they looked after the sick baby without personal protective measures.[12] 


\section{Discussion}

In this study we have reviewed the early data on the likelihood of infection, clinical presentation and outcomes, and transmission of COVID-19 in children. The majority of data were from China, and may be subject to ascertainment bias, either due to a higher than known proportion of milder cases in both adults and children, or due to selective ascertainment and testing bias towards adults with acute respiratory symptoms and limitations in diagnostic capacity. A number of the studies examined are pre-prints and have not been subjected to peer-review.

Nevertheless, we identify that children appear to be less affected by COVID-19 than adults by observed rate of infection; while $17.8 \%$ of the population were aged $0-15$ years old, only $2.1 \%$ of reported cases in a large case series from China were in the 0-19 age group.[22] However, a preprint paper[11] reports that children under 10 who were potentially exposed to the virus were just as likely to become infected as other age groups in the population. Low observed rates of infection and similar susceptibility to infection could be explained by differences in symptomatic infection rates. Other factors may have included social distancing methods, such as school closures. It should also be noted that the age profile of the population in China is unusual, in that few children will have siblings, but will usually have two parents and up to four grandparents. Critically, serological data are missing at this stage in the pandemic, without which uncertainty about infection rates is likely to persist.

Reliable evidence about clinical features and outcomes of COVID-19 in children is limited to small case series and case reports. Key emerging themes from the literature include description of generally mild symptoms[12] and several reports of asymptomatic infections,[9,13-16] with some indication from a case series of 105 children in Wuhan that there have been severe cases (7.6\%).[17] Rarely, paediatric deaths have also been reported.[18] We found no detailed studies of transmission of SARS-CoV-2 from children. Many of the childhood cases are from familial clusters with children 
identified through contact tracing of adult cases. $[19,20]$ There is only one case describing likely transmission from a 3-month-old infant to her parents after they looked after the unwell infant without personal protective measures.[12] Of note is the high frequency of chest radiographic abnormality described in both mild and asymptomatic infections in children. Longitudinal data will be required to understand the duration, persistence and functional deficit related to these findings.

We detected only a weak signal that children with comorbidities are at increased risk or are overrepresented among paediatric COVID-19 cases. This is broadly in line with a review of 14 paediatric MERS cases of whom nine without underlying disease remained healthy and three developed mild respiratory symptoms; the remaining two cases had significant comorbidities, developed severe respiratory symptoms, were treated in intensive care and subsequently died. Given that poor COVID-19 outcomes have been seen in adults with underlying conditions, a similar issue in children might be anticipated when sufficient data are available. Typically, a paediatric population may contain about $10 \%$ of children with one or more of the following: prematurity with chronic lung disease; cancer; genetic conditions such as cystic fibrosis and alpha 1 antitrypsin deficiency; chronic asthma and mucosal immune defects.[23] More evidence is therefore needed about clinical features and outcomes in children with high-risk conditions.

So far there has been only one documented case of transmission of SARS-CoV-2 from a child to an adult, though if infection rates are as high in children as in adults, as described by Bi et al,[11] it would be highly implausible that children were not infecting adults in a more widespread way. The WHO-China Joint Mission was unable to shed any light on this beyond anecdotally reporting no transmission from children.[7] One study attempts to assess the impact of Hong Kong's public health measures and population behaviour change on COVID-19 transmission, using routine influenza surveillance data as a proxy, assuming that influenza and COVID-19 are likely transmitted in similar ways.[24] The authors demonstrate the substantial impact that familiar public health measures 
(including school closure), social-distancing and behavioural change could have in slowing down COVID-19 transmission, though questions remain about whether these measures can avoid fatigue and be sustained in the long term.

While the evidence we reviewed related mainly to data from China, as the COVID-19 pandemic spreads worldwide, data are beginning to emerge from other countries, including Italy, [25] South Korea,[26] Iceland,[27] and the USA.[28] These reports corroborate our findings of lower observed rates of infection in children,[25-28] a milder disease course,[28] and asymptomatic cases having a role in transmission. [27,28] Varying public health measures and testing policies between countries should be noted in such comparisons.

It is informative to compare our findings with the literature for SARS-CoV and MERS-CoV, while data on SARS-CoV-2 are emerging. The majority of documented cases of SARS-CoV occurred in adults, in whom SARS was a severe respiratory disease characterised by fever and dyspnoea which could progress rapidly to ARDS and death.[29] Paediatric infection rates in SARS-CoV were low (135 cases in patients aged $<18,0.01 \%)$ with no deaths reported. The evidence is clear that young children $(<12$ years-of-age) generally had a milder course which had resolved by day 7 , and that symptoms in teenagers were more akin to those in adults.[30-36] Follow up studies in 47 SARS-CoV infected children who were asymptomatic detected abnormal imaging (HRCT) in 16/47, abnormal lung function in 4/47[11] and another study that followed up 34 affected children revealed reduced aerobic capacity at both six and 15 months post diagnosis.[37] It will be important to be alert for similar long term consequences for children infected by SARS-CoV-2.

There is little high-quality evidence relating to transmission of SARS-CoV in children. Public awareness of infection was high in the community and parents were instructed to keep their child off school if they had fever or respiratory symptoms, and so there was no documented spread in 
schools.[33] One seroprevalence study for SARS-CoV in children compared those residing in a district with a point source outbreak compared to a low risk area.[38] Seroprevalence in both areas was low (0.6\% in the high-risk area, $0 \%$ in the low-risk area, with positive children having reported no SARScompatible symptoms). This would suggest that positive serology for SARS-CoV in healthy asymptomatic children was very uncommon (0.57\%), suggesting a low rate of asymptomatic infection (in possible contrast to SARS-CoV-2), and that community transmissibility of this virus was low.

There are even fewer data relating to MERS-CoV in children. The majority of documented cases of MERS-CoV were in adults. There were 31 reported cases of MERS in children out of a global total of 2449 cases to June 2019 (0.01\%). Notably, 13 of 31 (42\%) were asymptomatic, identified through contact tracing. Of the 31 children, two who had underlying comorbidities died.[39] There is no evidence on transmission of MERS-CoV from children to adults. 


\section{Conclusion}

From large datasets in China, COVID-19 has been observed in children and young people at a low rate relative to the adult population. Limited data on attack rate suggests that children under 10 are infected with SARS-CoV-2 at roughly the same rates as adults. Children may be asymptomatic or too mildly infected to draw medical attention, be tested and counted in observed cases of COVID-19. Societal measures to limit the spread of the outbreak and household configuration in China (as a legacy of the 'one-child' policy) may limit generalisability to other countries or settings.

Evidence suggests that the clinical course in young children is milder than in adults, although there is a paucity of data and less is known about the course in adolescents. There are several reports of asymptomatic infection in children, which would appear to be consistent with emerging data relating to infection rates. There are, as yet, inadequate data on transmissibility of SARS-CoV-2 from children to other children. More evidence is required on all aspects of COVID-19 in paediatric populations including seroprevalence studies when an assay is available and long term follow up of silent radiographic abnormalities. 


\section{Contributions:}

NM, OMytton, EM, TF, CF, OMurphy, WJ and JSNVT wrote the paper. NM, WJ and OMurphy devised and coordinated the literature search and data extraction. NM, OMytton, EM, TF, CF, CL and DE extracted the data. JSNVT critically reviewed the data. All authors reviewed and contributed towards revising the final manuscript for important intellectual content.

All authors are, or have been, affiliated to, seconded to or employed by the Department of Health and Social Care (DHSC), England. The views in this manuscript are those of the authors and do not necessarily represent the official views of DHSC or HM Government.

\section{Acknowledgements:}

Claire Blackmore, Alicia Demirijan, David Evans, Adam Finn, Clare Gregory, Mike Linney, Helen

Mactier, Simon Nadel, Andrew Oakes, Andrew Pollard, John Reynolds, Calum Semple, Russell Viner, Hongxin Zhao.

Funding: No funding was received for this work

Conflicts of Interest: The authors declare no conflicts of interest related to this work 


\section{References}

1 Li Q, Guan X, Wu P et al. Early Transmission Dynamics in Wuhan, China, of Novel CoronavirusInfected Pneumonia. N Engl J Med. 2020;1-9. Available from:

https://www.nejm.org/doi/full/10.1056/NEJMoa2001316

2 World Health Organization. Coronavirus disease 2019 (COVID-19) Situation Report - 51. World Health Organization, 11 Mar 2020. Available from: https://www.who.int/docs/defaultsource/coronaviruse/situation-reports/20200311-sitrep-51-covid-19.pdf

3 Ison MG, Lee, N. Noninfluenza Respiratory Viruses. In: Cohen J, Powderly W, Opal S, eds. Infectious Diseases. 4th ed. Online: Elsevier; 2017. Vol 22017 p. 1472-1482. Available from: https://doi.org/10.1016/B978-0-7020-6285-8.00173-8

4 World Health Organization, Department of Communicable Disease Surveillance and Response. Consensus document on the epidemiology of severe acute respiratory syndrome (SARS). World Health Organization 2003. Available from:

https://www.who.int/csr/sars/en/WHOconsensus.pdf

5 World Health Organization. Middle East respiratory syndrome coronavirus (MERS-CoV), MERS Monthly Summary, November 2019. World Health Organization 2019. Available from:

\section{https://www.who.int/emergencies/mers-cov/en/}

6 Choi S, Jung E, Choi BY et al. High reproduction number of Middle East respiratory syndrome coronavirus in nosocomial outbreaks: mathematical modelling in Saudi Arabia and South Korea. J Hosp Infect. 2018 Jun;99(2):162-168. doi: 10.1016/j.jhin.2017.09.017. Epub 2017 Sep 25. Available from: https://www.ncbi.nlm.nih.gov/pubmed/28958834

$7 \quad$ World Health Organization. Report of the WHO-China Joint Mission on Coronavirus Disease 2019 (COVID-19), 16-24 February 2020. World Health Organization 2020. Available from:

https://www.who.int/docs/default-source/coronaviruse/who-china-joint-mission-oncovid-19-final-report.pdf

8 Wang P, Lu J, Jin Y et al. Epidemiological characteristics of 1212 COVID-19 patients in Henan, 
China. medRxiv. 2020;2020.02.21.20026112. Available from:

https://www.medrxiv.org/content/10.1101/2020.02.21.20026112v2

Wei M, Yuan J, Liu Y et al. Novel Coronavirus Infection in Hospitalized Infants Under 1 Year of Age

in China. JAMA - Journal of the American Medical Association [Internet]. Research Letter 2020;2. Available from: https://jamanetwork.com/journals/jama/fullarticle/2761659

Sun K, Chen J, Viboud C. Early epidemiological analysis of the coronavirus disease 2019 outbreak based on crowdsourced data: a population-level observational study. Lancet Digit Heal [Internet]. 2020;0(0). Available from:

https://linkinghub.elsevier.com/retrieve/pii/S2589750020300261

11 Bi Q, Wu Y, Mei S et al. Epidemiology and Transmission of COVID-19 in Shenzhen China: Analysis of 391 cases and 1,286 of their close contacts. medRxiv Prepr. Available from:

https://www.medrxiv.org/content/10.1101/2020.03.03.20028423v1.full.pdf

12 Cai J, Xu J, Lin D et al. A case series of children with 2019 novel coronavirus infection: clinical and epidemiological features. Clin Infect Dis 2020. Feb 28 (Epub ahead of print). Available from: https://academic.oup.com/cid/advance-article/doi/10.1093/cid/ciaa198/5766430 Chan JFW, Yuan S, Kok KH et al. A familial cluster of pneumonia associated with the 2019 novel coronavirus indicating person-to-person transmission: a study of a family cluster. Lancet [Internet]. 2020;395(10223):514-23. Available from: http://dx.doi.org/10.1016/S0140-

\section{$\underline{6736(20) 30154-9}$}

Pan X, Chen D, Xia Y et al. Asymptomatic cases in a family cluster with SARS-CoV-2 infection.

Lancet Infect Dis [Internet]. 2020;3099(20): Published online February 19,2020. Available from: http://dx.doi.org/10.1016/S1473-3099(20)30114-6

Kam K, Yung CF, Cui L et al. A Well Infant with Coronavirus Disease 2019 (COVID-19) with High Viral Load, Clin Infect Dis. 2020 Feb 28. pii: ciaa201. doi: 10.1093/cid/ciaa201. [Epub ahead of print] Available from: https://doi.org/10.1093/cid/ciaa201 
10.3760/cma.j.issn.0578-1310.2020.0007. [Epub ahead of print] [Article in Chinese; Abstract

available in Chinese from the publisher] Available from:

https://www.ncbi.nlm.nih.gov/pubmed/32061200

Yu H, Shao J, Guo Y, Xiang Y et al. Data-driven discovery of clinical routes for severity detection in COVID-19 pediatric cases. MedRixv [pre-print] 10 March 2020. Available from:

https://doi.org/10.1101/2020.03.09.20032219

The Novel Coronavirus Pneumonia Emergency Response Epidemiology Team Vital Surveillances: The Epidemiological Characteristics of an Outbreak of 2019 Novel Coronavirus Diseases (COVID19) - China, 2020. China CDC Wkly [Internet]. 2020;2(8):113-22. Available from: http://www.ourphn.org.au/wp-content/uploads/20200225-Article-COVID-19.pdf Chuming C, Cao M, Peng L et al. Coronavirus Disease-19 Among Children outside Wuhan, China. Lancet Child Adolesc, Manuscript Draft - Number: THELANCETCHILDADOL-D-20-00121. Available from: $\underline{\text { https://ssrn.com/abstract=3546071 }}$

Xia W, Jianbo S, Guo Y et al. Clinical and CT features in pediatric patients with COVID-19 infection: Different points from adults. Pediatr Pulmonol, 05 March 2020 (original article Infect Immun, 26 February 2020). DOI: 10.1002/ppul.24718

21 Lu Q, Shi Y. Coronavirus disease (COVID-19) and neonate: What neonatologist need to know. J. Med. Virol. 01 March 2020. Available from: https://doi.org/10.1002/imv.25740 Statista Research Department. Population distribution in China in 2019, by broad age group. Statista Research Department, Mar 5, 2020. Available from: https://www.statista.com/statistics/251524/population-distribution-by-age-group-inchina/

The March of Dimes Foundation, The Partnership for Maternal, Newborn \& Child Health, Save The Children, World Health Organization. In: Howson CP, Kinney MV, Lawn JE, eds. Born Too Soon: The Global Action Report on Preterm Birth. World Health Organization; New York, NY, USA: 2012. pp. 1-112. Available from:

https://www.who.int/pmnch/media/news/2012/201204 borntoosoon-report.pdf 
COVID-19 using influenza transmission as proxy in Hong Kong, February 2020 an observational study. Lancet. 2020; Draft Manuscript (February 2020).

The COVID-19 Task force of the Department of Infectious Diseases and the IT Service Istituto Superiore di Sanità. Integrated surveillance of COVID-19 in Italy. Available from:

https://www.epicentro.iss.it/en/coronavirus/bollettino/Infografica 7aprile\%20ENG.pdf

Statista Research Department. Age distribution of coronavirus (COVID-19) cases in South Korea as of April 16, 2020. Statista Research Department. Available from:

https://www.statista.com/statistics/1102730/south-korea-coronavirus-cases-by-age/

Gudbjartsson DF, Helgason A, Jonsson $\mathrm{H}$, et al. Spread of SARS-CoV-2 in the Icelandic Population.

New England Journal of Medicine. April 14, 2020 DOI: 10.1056/NEJMoa2006100

Coronavirus Disease 2019 in Children - United States, February 12 - April 2, 2020. Morbidity and Mortality Weekly Report 2020;69:422-426. DOI:

http://dx.doi.org/10.15585/mmwr.mm6914e4

Donnelly CA, Ghani AC, Leung GM et al. Epidemiological determinants of spread of causal agent of severe acute respiratory syndrome in Hong Kong. Lancet 2003. 361: 1761-6

Van Bever HP, Chng SY, Goh DY. Childhood severe acute respiratory syndrome, coronavirus infections and asthma. Pediatr Allergy Immunol. 2004;15(3):206-9. Available from:

https://www.ncbi.nlm.nih.gov/pubmed/15209951

31 Leung CW, Kwan Y, Ko P et al. Severe acute respiratory syndrome among children. Pediatrics. 2004;113(6). Available from: https://www.ncbi.nlm.nih.gov/pubmed/15173534

32 Bitnun A, Read S, Tellier R et al. Severe acute respiratory syndrome-associated coronavirus infection in Toronto children: A second look. Pediatrics. 2009;123(1):97-101. Available from: https://www.ncbi.nlm.nih.gov/pubmed/?term=Severe+acute+respiratory+syndromeassociated+coronavirus+infection+in+Toronto+children 
https://www.ncbi.nlm.nih.gov/pubmed/12950037

Zeng QY, Liu L, Zeng HS et al. Clinical characteristics and prognosis of 33 children with severe acute respiratory syndrome in Ghangzhou area. Chinese J Pediatr [Internet]. 2003;41(6):408-12. Available from: https://www.ncbi.nlm.nih.gov/pubmed/14748989 Ng PC, Leung CW, Chiu WK, Wong SF, Hon EK. SARS in newborns and children. Biol Neonate 2004;85:293-298. DOI: 10.1159/000078174. Available from: http://europepmc.org/article/MED/15218286 Chiu WK, Cheung PCH, Ng KL, et al. Severe acute respiratory syndrome in children: Experience in a regional hospital in Hong Kong. Pediatr Crit Care Med. 2003;4(3):279-83. Yu CCW, Li AM, So RCH et al. Longer term follow up of aerobic capacity in children affected by severe acute respiratory syndrome (SARS). Thorax. 2006;61(3):240-6. Lee PPW, Wong WHS, Chiu SS et al. Risk-stratified seroprevalence of SARS coronavirus in children residing in a district with point-source outbreak compared to a low-risk area. Hong Kong Med J. 2008;14(SUPP4):17-20. Available from:

https://www.hkmj.org/system/files/hkm0808sp4p17.pdf

39 Memish ZA, Al-Tawfiq JA, Assiri A et al. Middle East respiratory syndrome coronavirus disease in children [Internet]. Pediatr Infect Dis J; 2014. p. 33(9):904-906. Available from: https://europepmc.org/article/med/24763193 
Date, Title of paper, Author(s)

\section{STUDY TYPE \& SYNOPSIS}

Expert consensus statement.

Peer reviewed (World Journal of Paediatrics).

Development of expert consensus statement on the diagnosis, treatment and prevention of COVID-19

infection in children. in children: experts' consensus statement. Shen $\mathrm{K}$ et al.

\section{WHAT DOES THE PAPER TELL} US?

Evidence of infection: Since the outbreak of 2019 novel coronavirus infection (COVID-19) in Wuhan City, China, by January 30, 2020, a total of 9692 confirmed cases and 15,238 suspected cases have been reported. Of these 28 were children aged 1 month to 17 years $(0.29 \%$ of confirmed cases $)$.

Clinical presentation: Most identified infected children have mild clinical manifestations. They have no fever or symptoms of pneumonia with a good prognosis. Most of them recover within 1-2 weeks after disease onset. Few may progress to lower respiratory infections.

Transmission: The majority of cases had close contact with infected cases or were part of a family cluster. Some children 'appeared' asymptomatic. This paper regards 'silent infection' as those individuals who test positive for coronavirus but have no apparent symptoms.

\section{Likelihood of infection: No direct} evidence of infection in children.

February 2020 Impact assessment of . Not peer reviewed (Draft manuscript as at March 06, 2020). non-pharmaceutical interventions against COVID-19 using influenza transmission as proxy in Hong Kong, Examination of influenza transmission after implementation of control measures and changes in population behaviours in Hong Kong in late January 2020 as a proxy for COVID-19.

February 2020 an observational study. Cowling B et al.
Clinical presentation: No direct clinical

Transmission: No data on transmission of COVID-19. Data on influenza activity as a proxy. There was a $44 \%$ reduction in transmissibility in the community (95\% CI 34-53\%) and 33\% reduction in transmissibility based on paediatric hospitalisation rates (95\% CI 24-43\%) following school closures. outcomes recorded.
302 February 2020

(Epub ahead of print at $05 / 02 / 2020$ )

Diagnosis and treatment recommendations for pediatric respiratory infection caused by the 2019 novel coronavirus. Chen ZM et al.
Consensus guidelines.

Peer reviewed (World Journal of Paediatrics).

Expert consensus guidelines developed to standardize the protocol for respiratory infection in children caused by COVID-19

\section{Evidence of infection: between \\ December (date unspecified) 2019 and January 31, $2020>20$ paediatric cases have been reported in China (including 10 in Zhejiang Province), aged 112 days- 17 years}

Clinical presentation: At the onset of the disease, infected children mainly present with fever, fatigue and cough which may be accompanied by nasal congestion, runny nose, expectoration, diarrhoea and 
headache. Most children had low to

moderate or no fever. Most have good

prognosis and in mild cases recover 1-2

weeks after disease onset. No deaths in

children. Dyspnoea, cyanosis and other

symptoms can occur as the condition

progresses, usually after 1 week of the

disease, accompanied by systemic toxic

symptoms such as malaise, restlessness,

poor feeding, appetite and reduced

activity.

Transmission: No data reported on transmission. Children mainly belong to family cluster cases.

\begin{tabular}{lll}
\hline 4 & 05 February 2020 & Opinion piece. \\
Diagnosis and & Peer reviewed (World Journal of \\
treatment of 2019 & Pediatrics). \\
novel coronavirus & Editorial on initial 28 paediatric \\
infection in children: & cases reported. \\
a pressing issue. & \\
Shen KL, Yang YH. &
\end{tabular}

Evidence of infection: 28 confirmed paediatric cases. Several had no obvious clinical symptoms at time of diagnosis, found by screening and CXR suggestive of pneumonia.

Clinical presentation: If symptomatic, usually presented with fever, dry cough, fatigue, nasal congestion, runny nose and GI symptoms. Mostly mild symptoms. All had good prognosis and recovered within 1-2 weeks. Only "a few" had lower respiratory tract infections. No severe cases or deaths reported in paediatric population.

Transmission: No direct evidence of transmission. All cases were part of familial clusters or close contact history.

\begin{tabular}{|c|c|c|}
\hline 5 & $\begin{array}{l}07 \text { February } 2020 \\
\text { A contingency plan } \\
\text { for the management } \\
\text { of the } 2019 \text { novel } \\
\text { coronavirus } \\
\text { outbreak in neonatal } \\
\text { intensive care units. } \\
\text { Wang J et al. }\end{array}$ & $\begin{array}{l}\text { Opinion piece. } \\
\text { Peer reviewed (Lancet Child and } \\
\text { Adolescent Health). } \\
\text { Expert consensus of a contingency } \\
\text { plan for the COVID-19 outbreak in } \\
\text { neonatal intensive care units, focused } \\
\text { on diagnostic and discharge criteria, } \\
\text { treatment, prevention, and control } \\
\text { strategies. }\end{array}$ \\
\hline
\end{tabular}

Evidence of infection: By February 05, 2020, the number of confirmed cases had exceeded 20,000. About 100 children were affected with the youngest being 30 hours after birth.

Clinical presentation: Most adults or children presented with mild flu-like symptoms. Disease severity: Concern discussed that neonates might be more susceptible to the virus due to immature immune systems. Advises infected mothers not to breast feed.

\section{Transmission: No direct report of} transmission.

\begin{tabular}{lll}
\hline 6 & 11 February 2020 & Opinion piece. \\
2019-nCoV: Polite & Unclear whether peer reviewed. \\
with children! & Expert review of selected studies of \\
Caselli D, Aricò M. & SARS, MERS and case study of \\
& & COVID-19 data in paediatrics.
\end{tabular}

Evidence of infection: Report 1 case of an asymptomatic child who tested positive to COVID-19.

Clinical presentation: Children are at minimal risk to develop new disease and 
virtually no risk of a fatal course. SARS data identifies $0 \%$ fatality rate in those $<18$. In MERS data a $2 \%$ fatality rate in children.

Transmission: None reported.

\begin{tabular}{lll}
\hline 7 & 14 February 2020 & Case series. \\
Novel Coronavirus & Unclear whether peer reviewed. \\
Infection in & Case reports of all infected infants in \\
Hospitalized Infants & China. Description of demographic, \\
& $\begin{array}{l}\text { Under 1 Year of Age } \\
\text { in China. }\end{array}$ & epidemiologic, and clinical features. \\
&
\end{tabular}

Evidence of infection: Nine infected individuals identified.

Clinical presentation: 8/9 infants symptomatic. Four had fever, 2 had mild upper respiratory tract symptoms. No ICU, no death, no severe complications

Transmission: All 9 infants had at least 1 adult family member infected with COVID19. One identified on contact tracing. Seven infants were reported to be either living in Wuhan or having family members who visited Wuhan, 1 had no direct linkage to Wuhan, and 1 had no information available.

Vital Surveillances: Unclear whether peer reviewed.

The Epidemiological Retrospective cohort, 72,314 cases of

Characteristics of an COVID-19, all cases identified

Outbreak of 2019 through China's Infectious Disease

Novel Coronavirus monitoring system up to February Diseases (COVID-19) 02, 2020.

- China, 2020.

The Novel

Evidence of infection: Out of 72,314 cases, $416(0.9 \%)$ were aged $0-9$ years and $549(1.2 \%)$ were aged $10-19$ years.

Clinical presentation: None presented. The case fatality rate in $0-9$ years $0 / 416$, $10-19$ years $1 / 549(0.2 \%)$.

Severity not reported by age group. For all cases $80.9 \%$ had mild illness.

Coronavirus

Pneumonia

Transmission: None reported.

Emergency Response

Epidemiology Team.

\begin{tabular}{ll}
\hline $9 \quad 16$ February 2020 \\
& Analysis of CT \\
& features of $\mathbf{1 5}$ \\
& Children with $\mathbf{2 0 1 9}$ \\
& novel coronavirus \\
infection. & \\
Feng K et al.
\end{tabular}

Case series - full text only available

Evidence of infection: 15 confirmed in Chinese. Unclear whether peer reviewed. cases of COVID-19, aged from 4 to 14 years old.

A retrospective analysis was performed on clinical data and chest CT images of 15 children diagnosed with COVID-19. Among the 15 children, there were 5 males and 10 females, aged from 4 to 14 years old.

Clinical presentation: Five of the 15 children were febrile and 10 were asymptomatic on presentation. For their first chest CT images, 6 patients had no lesions, while 9 patients had pulmonary inflammation lesions. Seven cases of small nodular ground glass opacities and 2 cases of speckled ground glass opacities were found.

Transmission: None reported.

\begin{tabular}{llll}
\hline 10 & $\begin{array}{l}\text { 19 February 2020 } \\
\text { Asymptomatic cases } \\
\text { in a family cluster } \\
\text { with SARS-CoV-2 } \\
\text { infection. }\end{array}$ & $\begin{array}{l}\text { Case report. } \\
\text { Peer reviewed (The Lancet infectious }\end{array}$ & $\begin{array}{l}\text { Evidence of infection: 1 child in family } \\
\text { cluseases) }\end{array}$ \\
$\begin{array}{l}\text { Case study of clinical characteristics } \\
\text { of family cluster of SARS-CoV-2 } \\
\text { (mother, 33, father, 35, 3-year-old }\end{array}$ & $\begin{array}{l}\text { Clinical presentation: Child was } \\
\text { asymptomatic. }\end{array}$ \\
\hline
\end{tabular}




\begin{tabular}{|c|c|c|c|}
\hline & & boy). & $\begin{array}{l}\text { Transmission: No data reported on } \\
\text { transmission. }\end{array}$ \\
\hline 11 & $\begin{array}{l}20 \text { February } 2020 \\
\text { Early } \\
\text { epidemiological } \\
\text { analysis of the } \\
\text { coronavirus disease } \\
2019 \text { outbreak based } \\
\text { on crowdsourced } \\
\text { data: a population- } \\
\text { level observational } \\
\text { study. } \\
\text { Sun K et al. }\end{array}$ & $\begin{array}{l}\text { Observational study. } \\
\text { Peer reviewed (The Lancet Digital } \\
\text { Health). } \\
\text { Population-level observational study } \\
\text { using data from a health-care- } \\
\text { oriented social network currently } \\
\text { streaming news reports on COVID- } \\
19 \text { from local and national Chinese } \\
\text { health agencies. Trends in the } \\
\text { epidemiology of COVID-19 } \\
\text { including outbreak progression } \\
\text { across China are assessed. }\end{array}$ & $\begin{array}{l}\text { Evidence for infection: Data for } 507 \\
\text { patients with COVID-19 reported. Few } \\
\text { patients }(13,3 \%) \text { were younger than } 15 \\
\text { years. Age profile of Chinese patients } \\
\text { adjusted for baseline demographics } \\
\text { confirmed a deficit of infections among } \\
\text { children. Relative risk of below } 0.5 \text { in } \\
\text { the under } 15 \text {-year-olds. } \\
\text { Clinical presentation: No data on clinical } \\
\text { presentation. No mortality in children. } \\
\text { Transmission: None reported. }\end{array}$ \\
\hline 12 & $\begin{array}{l}25 \text { February } 2020 \\
\text { Are children less } \\
\text { susceptible to } \\
\text { COVID-19? } \\
\text { Lee P et al. }\end{array}$ & $\begin{array}{l}\text { Opinion piece. } \\
\text { Not peer reviewed (Journal pre- } \\
\text { proof). } \\
\text { Describes Chinese CDC data, } \\
\text { compares infection rates in other } \\
\text { pandemics and infections. Speculates } \\
\text { as to differences in immune systems } \\
\text { and viral receptors by age. } \\
\text { Not peer reviewed (Journal pre- } \\
\text { proof). }\end{array}$ & $\begin{array}{l}\text { Clinical presentation: None reported. } \\
\text { Transmission: No direct evidence of } \\
\text { transmission. Authors suggest that lower } \\
\text { infection rates in children may be due to } \\
\text { them undertaking less international } \\
\text { travel and outdoor activities. }\end{array}$ \\
\hline 13 & $\begin{array}{l}25 \text { February } 2020 \\
\text { (medRxiv preprint) } \\
\text { Epidemiological } \\
\text { characteristics of } \\
\text { 1212 COVID-19 } \\
\text { patients in Henan, } \\
\text { China. } \\
\text { Wang P et al. }\end{array}$ & $\begin{array}{l}\text { Observational study. } \\
\text { Not peer reviewed (medRxiv } \\
\text { preprint). } \\
\text { Cross-sectional analysis of publicly } \\
\text { available data. }\end{array}$ & $\begin{array}{l}\text { Evidence of infection: Out of } 1212 \\
\text { COVID-19 there were } 24 \text { cases aged } 0- \\
10 \text { years }(1.98 \%) \text {, and } 21 \text { cases aged } 11- \\
20 \text { years }(1.73 \%) \text {. } \\
\text { Clinical presentation: None reported. } \\
\text { Transmission: None reported. }\end{array}$ \\
\hline 14 & $\begin{array}{l}26 \text { February } 2020 \\
\text { Clinical and CT } \\
\text { features in pediatric } \\
\text { patients with } \\
\text { COVID- } 19 \\
\text { infection: Different } \\
\text { points from adults. } \\
\text { Xia W et al. }\end{array}$ & $\begin{array}{l}\text { Case series. } \\
\text { Peer reviewed (Paediatric } \\
\text { Pulmonology). } \\
\text { Case series of } 20 \text { paediatric patients } \\
\text { from Wuhan's children's hospital, } \\
\text { presenting January } 23 \text { to February } \\
\text { 08, 2020; primarily aimed at } \\
\text { description of radiological features. }\end{array}$ & $\begin{array}{l}\text { Evidence of infection: All cases } \\
\text { confirmed by pharyngeal swab COVID- } \\
19 \text { nucleic acid test. } 7 / 20 \text { had underlying } \\
\text { conditions (congenital). } \\
\text { Clinical presentation: None reported. } \\
\text { Noted that } 18 / 20 \text { had recovered. Mean } \\
\text { length of hospital stay of } 13 \text { days. } \\
\text { Transmission: No evidence that children } \\
\text { transmitted the virus. } 13 / 20 \text { cases had } \\
\text { familial contacts with COVID-19. }\end{array}$ \\
\hline 15 & $\begin{array}{l}28 \text { February } 2020 \\
\text { Report of the WHO- } \\
\text { China Joint Mission } \\
\text { on Coronavirus } \\
\text { Disease } 2019 \\
\text { (COVID-19) 16-24 } \\
\text { February 2020. } \\
\text { WHO. }\end{array}$ & $\begin{array}{l}\text { Consensus report. } \\
\text { Unclear whether peer reviewed. } \\
\text { The Joint Mission consisted of } 25 \\
\text { national and international experts } \\
\text { over a 9-day period and included } \\
\text { workshops and visits to regions } \\
\text { around China. }\end{array}$ & $\begin{array}{l}\text { Likelihood of infection: A low attack } \\
\text { rate in children was presented ( } 2.4 \% \text { of } \\
\text { all cases). In the absence of serological } \\
\text { studies, it is not possible to determine } \\
\text { the extent of infection among children. } \\
\text { In the included data, infected children } \\
\text { were largely identified through } \\
\text { household contact tracing of adults. }\end{array}$ \\
\hline
\end{tabular}


Clinical presentation: No data was presented on clinical outcomes in children. A very small proportion of those aged under 19 years have developed severe $(2.5 \%)$ or critical disease $(0.2 \%)$.

Transmission: No data was presented on transmission of illness in children. Of note, people interviewed by the Joint Mission Team could not recall episodes in which transmission occurred from a child to an adult.

\begin{aligned} \hline 16 & 01 March 2020 \\ & Coronavirus disease \\ & (COVID-19) and \\ & neonate: What \\ & neonatologist need to \\ & know. \end{aligned}

Lu Q, Shi Y.

\author{
Expert review. \\ Peer reviewed (Journal of Medical \\ Virology). \\ Review of reported case \\ characteristics.
}

Evidence of infection: From first confirmed child case on January 20, 2020 to February 06, 2020 at least 230 COVID-19 cases in children ( $\leq 18$ years) have been reported in China.

Clinical presentation: SARS-CoV-2 infection can range from asymptomatic infection to severe respiratory distress in neonate and children; Respiratory distress occur in children with underlying conditions.

The three newborns identified had short breath, vomiting of milk, cough and fever. Vital signs of those neonates were stable.

Transmission: There is currently no evidence that SARS-CoV-2can be transmitted trans placentally from mother to the newborn.

\begin{tabular}{|c|c|c|c|}
\hline 17 & $\begin{array}{l}02 \text { March } 2020 \\
\text { Clinical analysis of } \\
31 \text { cases of } 2019 \\
\text { novel coronavirus } \\
\text { infection in children } \\
\text { from six provinces } \\
\text { (autonomous region) } \\
\text { of northern China. } \\
\text { Wang D et al. }\end{array}$ & $\begin{array}{l}\text { Case series. } \\
\text { Unclear whether peer reviewed. } \\
\text { Case series in } 31 \text { children aged } 6 \\
\text { months to } 17 \text { years confirmed with } \\
\text { COVID-19 infection. Describes } \\
\text { epidemiological history, clinical } \\
\text { manifestations, treatment and the } \\
\text { short-term prognosis. }\end{array}$ & $\begin{array}{l}\text { Evidence of infection: Among the } 31 \\
\text { children, } 28 \text { patients }(90 \%) \text { were family } \\
\text { cluster cases. Nine cases }(29 \%) \text { were } \\
\text { imported, } 21 \text { cases had contact with } \\
\text { confirmed infected adults. One case } \\
(3 \%) \text { had contact with asymptomatic } \\
\text { returnees from Wuhan. } \\
\text { Clinical presentation: Common } \\
\text { symptoms were fever ( }=20,65 \%) \text {, } \\
\text { including } 1 \text { case of high fever, } 9 \text { cases of } \\
\text { moderate fever, } 10 \text { cases of low fever. }\end{array}$ \\
\hline
\end{tabular}


Fever lasted from 1 day to 9 days. The

fever of fifteen cases lasted for $\leq 3 \mathrm{~d}$, while in other 5 cases lasted $>3 \mathrm{~d}$. Other symptoms included cough $(\mathrm{n}=14,45 \%)$, fatigue $(n=3,10 \%)$ and diarrhoea $(n=3$, 9\%). Pharyngalgia, runny nose, dizziness, headache and vomiting were rare. The clinical types were asymptomatic type in 4 cases (13\%), mild type in 13 cases (42\%), and common type in 14 cases (45\%). No severe or critical type where identified. Among them, 24 children (77\%) recovered and were discharged from hospital (unclear if remaining were affected at time of publication or had chronic issues). No death occurred.

Transmission: None reported.

\begin{tabular}{|c|c|c|c|}
\hline 18 & $\begin{array}{l}03 \text { Mar } 2020 \\
\text { Coronavirus Disease- } \\
19 \text { Among Children } \\
\text { outside Wuhan, } \\
\text { China. } \\
\text { Chuming C et al. }\end{array}$ & $\begin{array}{l}\text { Case series. } \\
\text { Not peer reviewed (Manuscript } \\
\text { Draft). } \\
\text { Prospective follow up of } 31 \\
\text { confirmed cases }<18 \text { years of age } \\
\text { with SARS-CoV-2 infection in } \\
\text { Shenzhen Third People's Hospital } \\
\text { between January } 16 \text { and February 19, } \\
2020 .\end{array}$ & $\begin{array}{l}\text { Evidence of infection: All } 31(7.9 \%) \\
\text { child cases of } 291 \text { cases were confirmed } \\
\text { as having SARS-CoV-2 } \\
\text { Clinical presentation: } 12(38.7 \%) \\
\text { children had no clinical symptoms, other } \\
2 / 3 \text { children had mild cases (no severe } \\
\text { cases in children). Most of children did } \\
\text { not have underlying conditions ( } 2 \text { [6.5\%] } \\
\text { patients had underlying diseases, one of } \\
\text { which had asthma, and the other had } \\
\text { duplicate kidneys.) }\end{array}$ \\
\hline & & & $\begin{array}{l}\text { Transmission: } 29(93.5 \%) \text { of the children } \\
\text { were in familial clusters. }\end{array}$ \\
\hline 19 & $\begin{array}{l}\text { 04 March } 2020 \\
\text { Epidemiology and } \\
\text { Transmission of } \\
\text { COVID-19 in } \\
\text { Shenzhen China: } \\
\text { Analysis of } 391 \text { cases } \\
\text { and } \mathbf{1 , 2 8 6} \text { of their } \\
\text { close contacts. } \\
\text { Bi Q et al. }\end{array}$ & $\begin{array}{l}\text { Observational study - full text only } \\
\text { available in Chinese. } \\
\text { Not peer reviewed (pre-print). } \\
\text { Shenzhen CDC identified } 391 \\
\text { SARS-CoV-2 cases from January } 14 \\
\text { to February } 12,2020 \text { and } 1286 \text { close } \\
\text { contacts. Cases identified through } \\
\text { symptomatic surveillance were } \\
\text { compared to those identified via } \\
\text { contact tracing. }\end{array}$ & $\begin{array}{l}\text { Evidence of infection: The household } \\
\text { secondary attack rate was } 15 \% \text {, and } \\
\text { children were as likely to be infected as } \\
\text { adults. Children reported to be similar } \\
\text { risk of infection as the general } \\
\text { population. } \\
\text { Clinical presentation: Children were } \\
\text { reported to have less severe symptoms } \\
\text { than adults. }\end{array}$ \\
\hline & & & Transmission: None reported. \\
\hline 20 & $\begin{array}{l}\text { 04 March } 2020 \\
\text { Clinical and CT } \\
\text { Imaging Features of } \\
\text { the COVID-19 } \\
\text { Pneumonia: Focus } \\
\text { on Pregnant Women } \\
\text { and Children. } \\
\text { Liu F et al. }\end{array}$ & $\begin{array}{l}\text { Case reports. } \\
\text { Not peer reviewed (Manuscript } \\
\text { Draft). } \\
\text { Clinical and CT data of } 59 \text { patients } \\
\text { with COVID-19 from January } 27 \text { to } \\
\text { February } 14,2020 \text { were } \\
\text { retrospectively reviewed, including } \\
14 \text { laboratory-confirmed non- } \\
\text { pregnant adults, } 16 \text { laboratory- } \\
\text { confirmed and } 25 \text { clinically- } \\
\text { diagnosed pregnant women, and } 4\end{array}$ & $\begin{array}{l}\text { Evidence of infection: Four lab } \\
\text { confirmed cases in children. } \\
\text { Clinical presentation: None reported. } \\
\text { Imaging had fully resolved in } 3 \text { out of } \\
\text { the } 4 \text { children. } \\
\text { Transmission: None reported. }\end{array}$ \\
\hline
\end{tabular}


laboratory-confirmed children.

\begin{tabular}{lll}
\hline 21 & 05 March 2020 & Case Series. \\
Clinical & Not peer reviewed (Manuscript \\
characteristics of & Draft). \\
COVID-19 in & Retrospective case series of 67 \\
children compared & consecutive hospitalized confirmed \\
with adults outside of & cases including 14 children with \\
Hubei Province in & COVID-19, January 23 to February \\
China. & $15,2020$. \\
Du W et al. &
\end{tabular}

Evidence of infection: There were 14 children confirmed cases among the 67 cases, with a median age of 6.2 years (range, 0-16years).

Clinical presentation: 3 cases $(21.4 \%)$ of the mild type and 11 cases $(78.6 \%)$ of the conventional type. No severe or critical cases. Diagnostic criteria for mild cases: mild clinical symptoms, noradiographic findings of pneumonia. Diagnostic criteria for common cases: fever, respiratory symptoms, and radiographic manifestations of pneumonia.

Transmission: All the cases in children were familial clusters.

2206 March 2020 (medRxiv preprint)

Preliminary epidemiological analysis on children and adolescents with novel coronavirus disease 2019 outside Hubei Province, China: an observational study utilizing crowdsourced data. Henry BM, Santos de Oliveira MH.

\author{
Observational study. \\ Not peer reviewed (medRxiv \\ preprint).
}

An observational study utilizing crowdsourced data outside of Hubei province (i.e. includes mainland China minus Hubei and rest of the world). Defined paediatric cases as patients $<19$ years of age with a lab confirmed diagnosis.
Evidence of infection: A total of 82 patients were included. 53 children were aged between $0-12$ years and 27 adolescents between 13-19 years. Limited evidence available.

Clinical presentation: When clinical features were reported, fever was the most common presentation $(68 \%)$ followed by cough (36\%). $2(8.0 \%)$ were asymptomatic.

Transmission: A total of $29(35.4 \%)$ patients were noted to have an infected family member.

\begin{tabular}{lll}
\hline 23 & 06 March 2020 & Case Series. \\
(medRxiv preprint) & Not peer reviewed (medRxiv \\
Transmission and & preprint). \\
clinical & Contact investigation was conducted \\
characteristics of & on each patient who admitted to the \\
coronavirus disease & assigned hospitals in \\
2019 in 104 outside- & Hunan Province (geographically \\
Wuhan patients, & adjacent to Wuhan) from January 22 \\
China. & to February 12, 2020. \\
Qiu C et al. &
\end{tabular}

$24 \quad 10$ March 2020 (medRxiv preprint)

Data-driven discovery of clinical routes for severity detection in COVID19 pediatric cases.

\section{Case Series.}

Not peer reviewed (medRxiv preprint).

Analysis of 105 cases of COVI-19 in children diagnosed between February 01 to March 03, 2020 from Wuhan Children's Hospital, Tongji Medical
Evidence of infection: 3 children within the 104 confirmed cases.

Clinical presentation: No data reported.

Transmission: Asymptomatic transmission exists (but example given was adult giving it to their child and to their parent). Family clusters were the major body of patients, with transmission along 3 generations within some families (although direction of transmission not specified).

Evidence of infection: 105 cases in children reported.

Clinical presentation: Of the 105, 64 were males and 41 were female. Clinical symptoms including shortness of breath, 
School, Huazhong University of Science and Technology, Wuhan (the sole designated hospital in Wuhan for COVID-19 children patients). assisted respiration, apnoea, cyanosis, dehydration, and progressive increase of lactate were noted. Disease severity: Of the 105 cases 8 were critically ill.

Transmission: None reported. 
Figure 1 PRISMA 2009 Flow Diagram 


\section{Figure 1: PRISMA 2009 Flow Diagram}

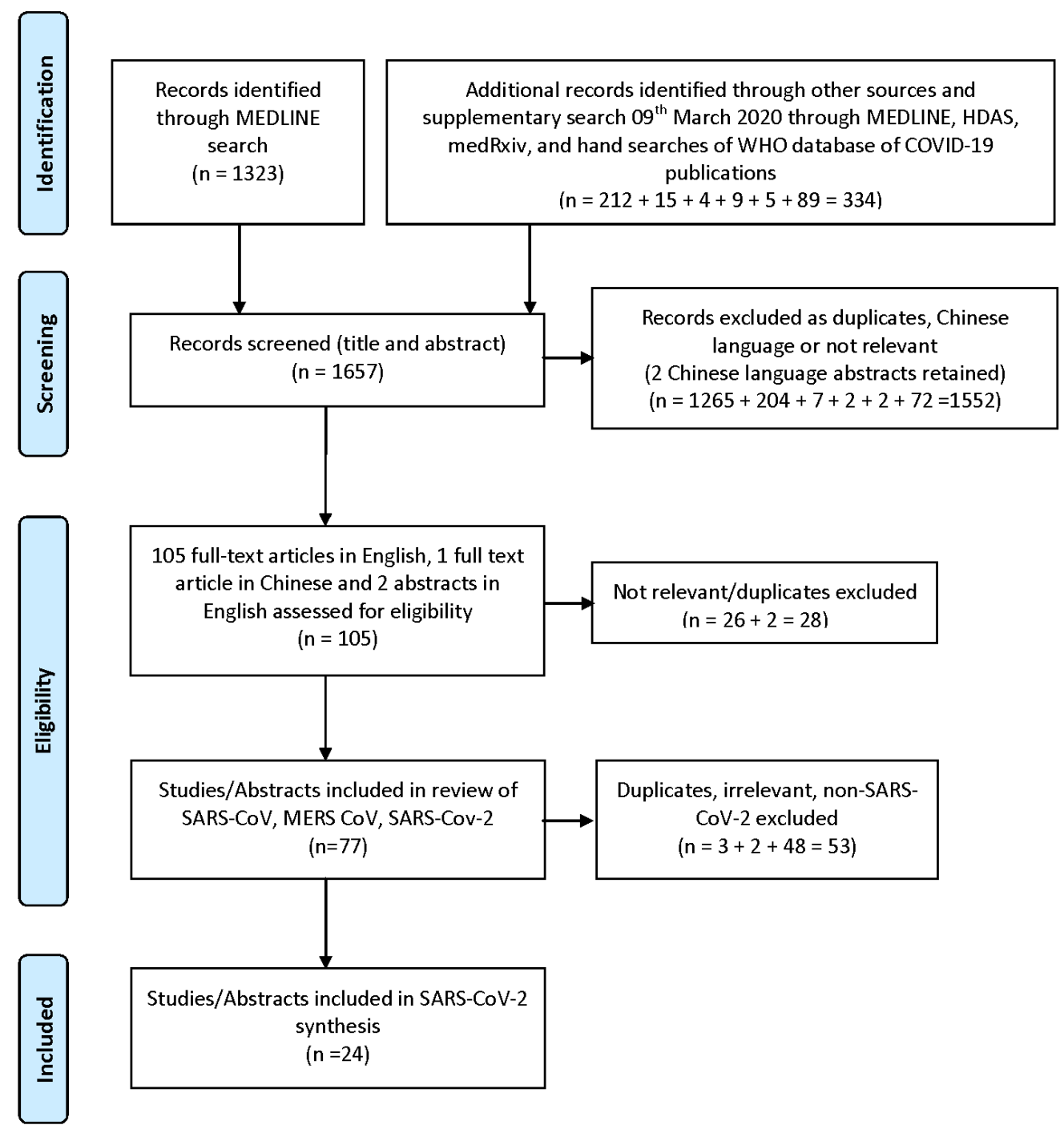

From: Moher D, Liberati A, Tetzlaff J, Altman DG, The PRISMA Group (2009). Preferred Reporting /tems for Systematic Reviews and MetaAnalyses: The PRISMA Statement. PLoS Med 6(7): e1000097. doi:10.1371/journal.pmed1000097

For more information, visit wuw. prisma-statement.org. 